\title{
Attacks on road-freight transporters: a threat to trade participation for landlocked countries in Southern Africa
}

\author{
Andrew Thomas Mlepo ${ }^{1}$ (I)
}

Received: 14 June 2021 / Accepted: 1 December 2021 / Published online: 27 January 2022

(c) The Author(s), under exclusive licence to Springer Science+Business Media, LLC, part of Springer Nature 2021

\begin{abstract}
South Africa hosts some of the busiest maritime ports which are gateway ports to several landlocked countries in the region. Road transportation is the main modality for moving goods between seaports and hinterland within South Africa and beyond to at least six landlocked countries in the region. However, the high rate of violent crime against freight trucks and vans has for many years been a major known risk to the road freight transport industry. Traditionally, these crimes have been motivated by monetary proceeds from sales of stolen goods from hijacked vehicles or the vehicles themselves. Recently, however, influenced by anti-immigrant sentiments, similar attacks have been specifically targeting foreign drivers and trucks resulting in death, injury, and damage to vehicles and cargo. Previously considered an internal problem for South Africa as a matter arising from domestic social and economic challenges in that country, the emergence of attacks on foreign drivers and trucks have raised concerns about the future of South Africa as an economic powerhouse, its role as a transit country for landlocked countries, and about its relationship with regional neighbors. For the landlocked countries in the region, any instability in South Africa can have a serious impact on the logistics that sustain businesses and international trade. This exploratory study gives an overview of the increasingly complex issue of violent attacks against foreign nationals in South Africa with a focus on attacks targeting the road freight transport sector and the implications on regional integration efforts.
\end{abstract}

Keywords Transport security · Road freight transport · LLDCs · Immigration · International trade

Andrew Thomas Mlepo

atmlepo@outlook.com

1 Transportation Engineering College, Dalian Maritime University, Dalian, China 


\section{Introduction}

South Africa is Africa's second-largest economy after Nigeria and it is the regional economic powerhouse of southern Africa with a GDP of 351.43 billion US dollars in 2019. It is home to some of Africa's busiest maritime ports which also facilitate imports and exports for several landlocked countries (henceforth, LLCs) countries in the southern African region. The ports include Durban, Richard's Bay, and Saldanha bay. Goods are transported primarily by road between these ports and landlocked neighbors including Botswana, Lesotho, Zimbabwe, Zambia, and Malawi. One of the most pressing issues for transport operators in South Africa has been criminal activities against cargo while in transit. These criminal activities have ranged from hijackings, theft, and arson which, in worst cases have resulted in the loss of life and total loss of cargo. The attacks as discussed in this paper refer to both recurring attacks as an organized crime by gangs and mass attacks that are triggered by social issues expounded in Section 2. Regardless of which party ultimately bears the cost of these crimes, the losses incurred are too significant to ignore for businesses that rely on transporting their goods on South African roads and a major concern for the countries in the Southern African region, and indeed the entire African continent.

\section{South Africa as a regional transit country and a trading partner}

Faye et al. (2004) argued that while the relatively poor performance of LLCs is attributed primarily to distance from the coast, several aspects of dependence on transit neighbors are also important, and they are: dependence on neighbors' infrastructure; dependence on sound cross-border political relations; dependence on neighbors' peace and stability; and dependence on neighbors' administrative practices. These factors combine to yield different sets of challenges and priorities in each LLC. With regards to dependence on infrastructure, Collier (Collier 2007) describes LLCs as hostages of their maritime neighbors when it comes to transportation costs which the study attributed to how sophisticated the maritime transit neighbors' transport infrastructure is. That study illustrates how the neighboring countries of Uganda and those of Switzerland facilitate trade and subsequently, development in each of the two countries with respect to transport infrastructure, both as trading partners and transit countries.

In the case of the Southern African region, South Africa is a key transit country for the region's LLCs for access to global markets through maritime transportation to import commodities that are essential for national economic activities including fuels, vehicles, heavy machinery, and pharmaceutical products as well as to export their resources and products to markets overseas.

In addition to being an important transit country in the region, the highly industrialized South Africa is also the region's key trading partner and the top exporter to regional neighbors with total export values of $\$ 453 \mathrm{M}, \$ 2.46 \mathrm{~B}$, and $\$ 2.77 \mathrm{~B}$ for Malawi, Zimbabwe, and Zambia, respectively in 2018. The limitations associated with current railway infrastructure in the country and the region, in general, mean 
that at least $70 \%$ of goods are transported by road. Unlike the rail transport infrastructure, South Africa has a considerably robust road infrastructure compared to its neighbors in the region and ranks relatively high on the global road quality index ${ }^{1}$.

Compared to rail transportation, road freight offers flexibility in terms of time and cost including negotiable back-haul cargo tariffs. South Africa, notably permits some of the largest vehicle combinations in the world for general freight haulage - an overall combination length of $22 \mathrm{~m}$ and load heights of $4.3 \mathrm{~m}$, permitting a load area of $124 \mathrm{~m}^{3}$ and 38 tons payloads and 56 tons gross vehicle mass (GVM) (Road Safety Administration 2019). The generous permissible vehicle carrying capacities and dimensions allow for road freight operators to offer competitive rates for the haulage of bulk commodities such as steel, fertilizer, cement, maize, timber, containers, and fuel. In 2019, 120 billion Rand (about 8.8 billion US Dollars) worth of goods was transported by freight companies on South African roads (Freewest media 2020).

\section{A background of violence against foreign nationals in South Africa}

To understand what drives attacks on foreign freight trucks and drivers today, it is important to first discuss the contentious relationship between locals and foreign workers, and business operators in South Africa. Although South Africa has some of the most well-defined and guarded borders in the region, some foreigners still manage to enter the country without proper documentation and join the informal sector or start businesses. Those businesses have been targeted in many instances and the recent repeated attacks on foreign freight transporters are simply a new extension to the violence. Most of the attacks targeting foreign-registered trucks or drivers have been against the background of grievances surrounding domestic social-economic issues such as the claim that the influx of immigrants into the country is taking away job opportunities, including truck driving, which they believe are meant for local people.

Over the recent years, resentment has grown over the employment of foreigners, especially in the informal sector, igniting sporadic attacks on immigrants and their businesses in the country. Most peculiar, however, is that most of the attacks have been directed at African-owned businesses (Fig. 1).

Looking at nature, motives, and increased intensity, which are very similar to the historical political violence which was drawn along racial lines, some authors have concluded that the recent attacks between 2008 and 2018 targeting African migrants in South Africa are characteristically selective xenophobia, and several studies on the subject published since 2015 have seen the increased usage of the term, Afrophobia (Tshishonga 2015, Thela, et al. 2017; Dube 2017; Waiganjo 2018; Masenya 2018).

\footnotetext{
1 Road quality is based on the extensiveness and condition of road infrastructure on a scale: $1=$ extremely poor-among the worst in the world to 7 =xtremely good-among the best in the world.
} 


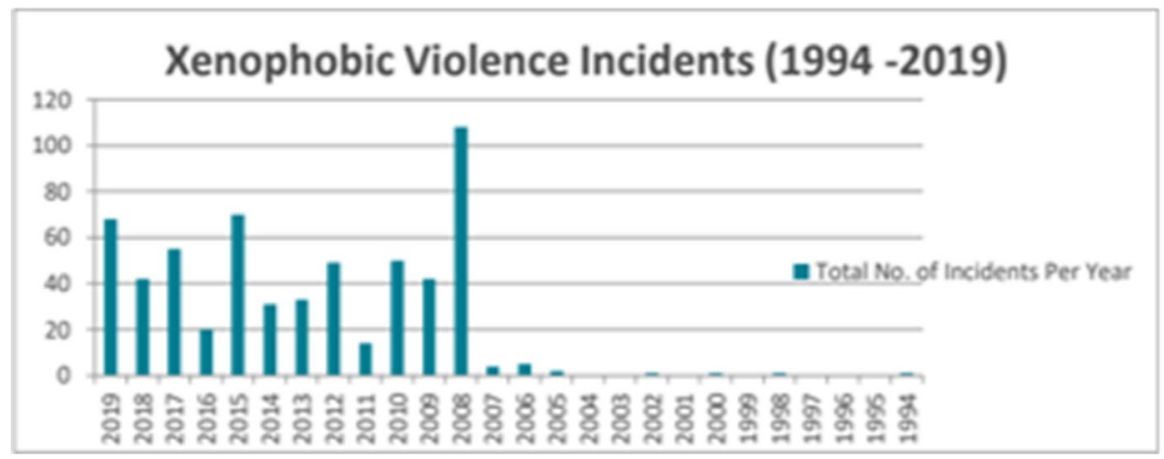

Fig. 1 Xenophobic violence incidents (1994-2019). Source: Mlilo (Mlilo 2019)

\section{Inequality, poverty, and unemployment}

The population of South Africa was estimated at 59.62 million in mid-2020 according to a survey report by the Department of Statistics South Africa (Department 2020). It has one of the highest inequalities in the world, with a Gini index score of 63. Having made no progress in addressing issues surrounding inequality from the previous years, it remains the most unequal country in the world. In South Africa, the wealthiest $10 \%$ hold over $50 \%$ of the country's income while the poorest share an estimated $7.2 \%$ of income, the highest deviation in the UN Human Development Index. Overall, the country ranked 114 out of the 189 countries assessed in the index. This extreme inequality is one of the contributors to high levels of poverty. Previous statistics indicated that at least half of the population lived under different levels of poverty. The world bank estimated that the impact of COVID-19 may have pushed well over a million people into extreme poverty in some countries including South Africa. With the pandemic and its effects yet to be contained, the number of people living in poverty will most likely continue to grow.

Unemployment is also rife in South Africa with the mid-2020 survey by the Department of Statistics estimating that 9.6 million people were unemployed, representing $30.8 \%$ of the unemployment rate in Q3,2020. The rate of unemployment had increased by $7.5 \%$ points from $23.3 \%$ in Q2, 2020. South Africa remains the hardest-hit country by the Covid-19 pandemic in Africa. One of the direct impacts of the pandemic has been the slowdown in economic activities which has subsequently led to at least 2 million job losses, and business losses whose estimates are yet to be established.

\section{Competition and resentment of foreigners over jobs}

In total, South Africa has approximately 2.2 million foreigners legally in the country and about one million undocumented foreign nationals, some claiming asylum. South Africa remains a key destination not only for immigrants from the Southern 
part of the African continent as any quick survey shows the presence of communities of people who originate from as far as Ethiopia, Somalia, Congo, and Burundi, among others. Interviews with immigrants revealed that for both asylum seekers seeks refuge from war-torn countries and economic immigrants, the perception of South Africa as a "rich nation" and high prospects of personal economic success in that country are key drivers to migration even when it means illegally crossing multiple borders to reach their destination. Once in South Africa, many undocumented foreigners seek employment in the informal sector while others who have the financial capital, set up businesses in various parts of the country. The employment of undocumented foreigners in the informal sector in South Africa, just like elsewhere around the world is characterized by low wages and poor conditions, but that does not stop foreigners from taking up jobs, anyway. This can easily be linked to the fact that compared to the currencies in their countries of origin, say for example Malawi, Zimbabwe, and Mozambique, the South African Rand is stronger and translates to larger sums when converted. Most of the workers in the informal industry use the wages they receive to help families they left behind in their home countries. The nature of the informal sector makes it relatively difficult to regulate and track the employment of migrants. Some studies have established that, in some areas of South Africa, foreigners create jobs and employ locals. However, as the businesses grow, there appeared to be a tendency to employ more immigrants. The detail of foreigners creating jobs for South Africans has had almost no impact on changing the attitude towards foreigners working or doing business in the country and resentment and tension remain high.

Apart from the informal sector and private businesses, there has been growing belief that migrants are taking over jobs in other sectors as well, and most recently the trucking industry has been in the spotlight. However contrary to this popular belief, the National Bargaining Council for the Road Freight and Logistics Industry of South Africa reports that $84.66 \%$ of the drivers are in fact, South African citizens. The council has in its records, a total of 44, 021 truck drivers, of which only 6, 756 or $15.34 \%$ are nationals of other countries. The stark difference between the claims such as "majority" and "taking over jobs" and the facts in this example are a clear illustration of how generally exaggerated the situation is with regards to the employment of nationals of other countries. Needless to say, such exaggerations have a catalytic effect in the recurring episodes of explosive violence against foreign nationals in the various parts of South Africa.

\section{Summary}

Poverty, unemployment, and inequality have been established as serious problems among the South African population. Researchers are yet to objectively establish a causal link between those problems and xenophobic attacks despite their apparent association. What is established, however, is that social and economic issues such as increases in income inequality raise crime rates and the persistence of crime over time (Fajnzylber et al. 2002). As will be discussed in Section 3.2, there are signs that criminal gangs to an extent yet unknown, contribute to the violent acts 
Table 1 Road quality index for select countries in Southern Africa

\begin{tabular}{|c|c|c|c|c|}
\hline \multirow[t]{2}{*}{ Country } & \multicolumn{2}{|l|}{$2016 / 2017$} & \multicolumn{2}{|l|}{$2017 / 2018$} \\
\hline & $\begin{array}{l}\text { Global Rank } \\
/ 138\end{array}$ & Score & $\begin{array}{l}\text { Global Rank } \\
/ 137\end{array}$ & Score \\
\hline Botswana & 62 & 4.1 & 80 & 3.8 \\
\hline Congo DRC & 137 & 2.1 & 136 & 2.1 \\
\hline Malawi & 112 & 2.9 & 117 & 2.8 \\
\hline Mozambique & 133 & 2.4 & 129 & 2.5 \\
\hline Namibia & 23 & 5.2 & 31 & 5 \\
\hline South Africa & 29 & 5 & 50 & 4.4 \\
\hline Tanzania & 90 & 3.4 & 90 & 3.5 \\
\hline Zambia & 85 & 3.5 & 86 & 3.6 \\
\hline Zimbabwe & 101 & 3.2 & 116 & 2.8 \\
\hline
\end{tabular}

Author's compilation based on data from World Economic Forum competitive reports $(2017 \& 2018)$

against foreign nationals, including truck drivers. Of the four dependences presented by Faye, et al. (2004), the elements of dependence on neighbors' infrastructure; dependence on sound cross-border political relations, and dependence on neighbors' peace and stability form the basis for discussion throughout this paper. They form a strong base considering how much the South African infrastructure facilitates regional trade, how violence against immigrants in that country has affected relations with neighbors, and how generally, any instability and other disruptive events impact the flow of goods to and from the LLCs in the region (Table 1).

\section{Violent property crime in South Africa}

Crime in South Africa is generally high even by global comparisons, and that includes violent property crimes such as hijacks and cargo theft while in transit. South Africa's crime index (77.07) is only surpassed by Papua New Guinea (80.24) and Venezuela (84.25). Violence and criminal activities in South Africa are exacerbated by well-documented drug and alcohol abuse, especially among the youth.

\section{Truck hijackings}

Carjacking small passenger vehicles, in general, has been prevalent in South Africa for many years. The difference between hijacking small vehicles and large freight trucks is that the latter is more lucrative considering the value of cargo or indeed, the trucks targeted. Due to the high-stake high-value nature of freight truck hijackings, attacks on freight trucks have proven to be much more meticulously organized and coordinated than small vehicle hijacks, making it very difficult for authorities to address the challenge. Although reasons for hijacking freight trucks may vary, theft of the contents is the primary objective for hijackers. In the period between March 2018 and June 2019, at least 200 people, mostly foreign truck drivers were 


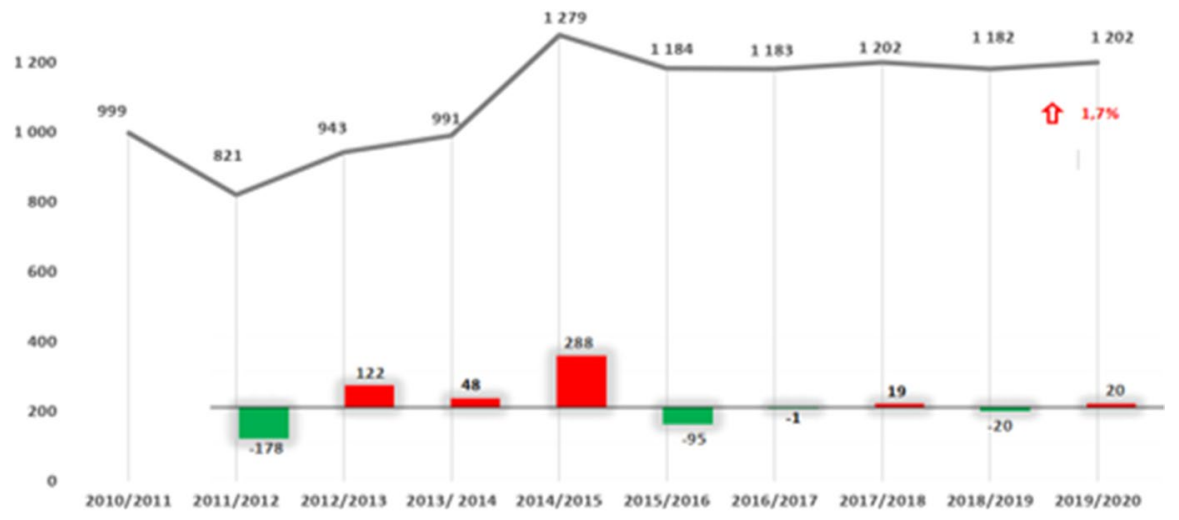

Fig. 2 10-year trend of truck hijacking in South Africa. Source: SAPS (2020)

killed and more than 1, 200 vehicles destroyed along with their cargo (HRW 2019) (Fig. 2).

At the provincial level in the 2019/2020 statistics, Gauteng recorded the most cases of truck hijacking with $52.33 \%$ of the total. Far behind that province is $\mathrm{Mpu}-$ malanga (11.98\%), Western Cape (10.73\%), Eastern Cape (10.32\%), Kwazulu Natal $(5.82 \%)$, Free State (3.66\%), North West (3\%), Limpopo (2.08\%), and Northern Cape (0.08\%), according to the South African Police Service (SAPS). From Table 2, the information on the regional distribution of incidents can help inform trucking companies on effective route planning to avoid high-risk areas. That, however, is only part-solution and falls short of guaranteeing total safety, considering the dynamic nature and the unpredictability of the problem at hand.

In addition to high numbers of hijackings, South Africa also records some of the highest cases of cargo theft in Africa. However, Burges (2009), suggested that the high rates of cargo theft reported in South Africa in comparison with other African countries might be attributed to the country's high level of industrialization which gives it the ability to measure and track crime and not necessarily mean that they are the highest. West African countries including Cameroon, Nigeria, Liberia, Togo, Ivory Coast, Togo, and Benin have the highest risk of cargo theft, according to numerous statistics and estimations.

The most available literature on cargo theft focuses on the nature and occurrences of facility-based theft of cargo where theft occurs on premises such as transshipment centers, warehouses, distribution centers, and a few studies on cargo-in-transit especially when trucks are parked. Trucks in transit, mobile or temporarily stationary, have been reported to be the primary modality for cargo theft in South Africa at $62 \%$ compared to followed by facility-based theft, sea, and pipeline modalities at $33 \%$, $3 \%$, and $2 \%$, respectively. Over the years, the crime targeting the transport industry in South Africa has been motivated by the money that is generated from either direct ambush of trucks transferring hard cash or proceeds from sales of hijacked containers, trailers, and merchandise. High-risk areas for cargo theft include Pretoria and Johannesburg in Gauteng province, Bloemfontein in Free State, Cape Town in 


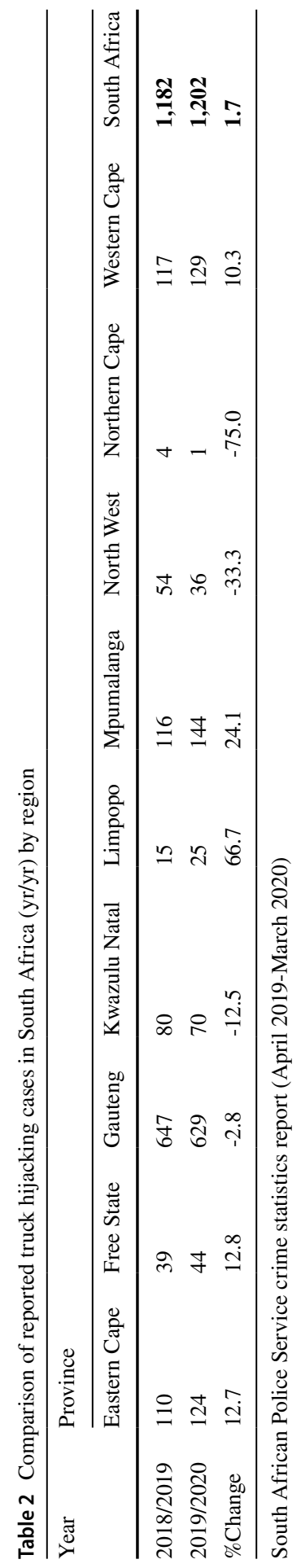


Western Cape, Port Elizabeth in Eastern Cape, and Durban in KwaZulu Natal (TT CLUB \& BSI SCREEN Intelligence 2020).

\section{The profile of perpetrators}

Just like pirates in maritime hijackings, land-based hijackers of freight carriers are constantly evolving in tactics and resourcefulness to sustain their illicit activities. Piracy in the Horn of Africa at its height in 2009 was running under structured and well-established clan-based chains of command and financing. Because of its scale, the impact on the shipping industry, and the open nature of transactions including the stock market listing of the piracy activities to source funds, the problem of maritime hijackings was well studied and understood by researchers and played a key role in informing decision-makers (Pristrom et al. 2013, Onuoha 2009, 2010). The primary difference in terms of function between the Somali maritime hijacking problem and the land-based freight truck hijacking problem in South Africa is the structure of the syndicates. Unlike in Somalia, the gangs that run the hijacking operations are not a visible part of the community and the mediums to gain an understanding of their tactics are through law enforcement surveillance, informants, and directly from the perpetrators when they have been apprehended by law enforcement. It must be highlighted at this juncture that, there are gangs that specialize in the hijacking of trucks on a full-time basis regardless of the nationality of the drivers whatsoever. In the waves of targeted violence against foreign drivers or trucks as motivated by indignation, community members have been seen actively participating in the attacks, thanks to video footages and still images shared across social media platforms and news outlets examined ${ }^{2}$ for this study. Although it is difficult to establish the degree to which criminal gangs participate in the attacks targeting foreigners, the sheer similarity in the methods that are used is incontrovertible evidence of a connection, influence, or indeed, direct involvement. This could easily be linked to the fact that, at the end of the day, the members of the criminal syndicates belong to various communities across the country.

\section{Modi operandi and countermeasures}

Broadly, the methods for attacks on transit freight trucks can be classified into staged and surprise attacks. In the former, seemingly innocent scenarios such as hitchhikers, staged breakdowns, collisions, or police roadblocks are set up to slow down trucks in secluded parts of highways. Once slowed down enough or completely stopped, an attack is launched often by several individuals at any given time. In surprise attacks, criminals target resting areas for truck drivers, unsecured parking lots, and where trucks naturally slow down or come to a complete stop, such as road junctions (Arrive Alive 2016). The primary objective of attacking freight trucks is to steal the goods in transit either in random surprise attacks or attacks on

\footnotetext{
${ }^{2}$ Web search using key words: Protesting South Africans burn trucks.
} 


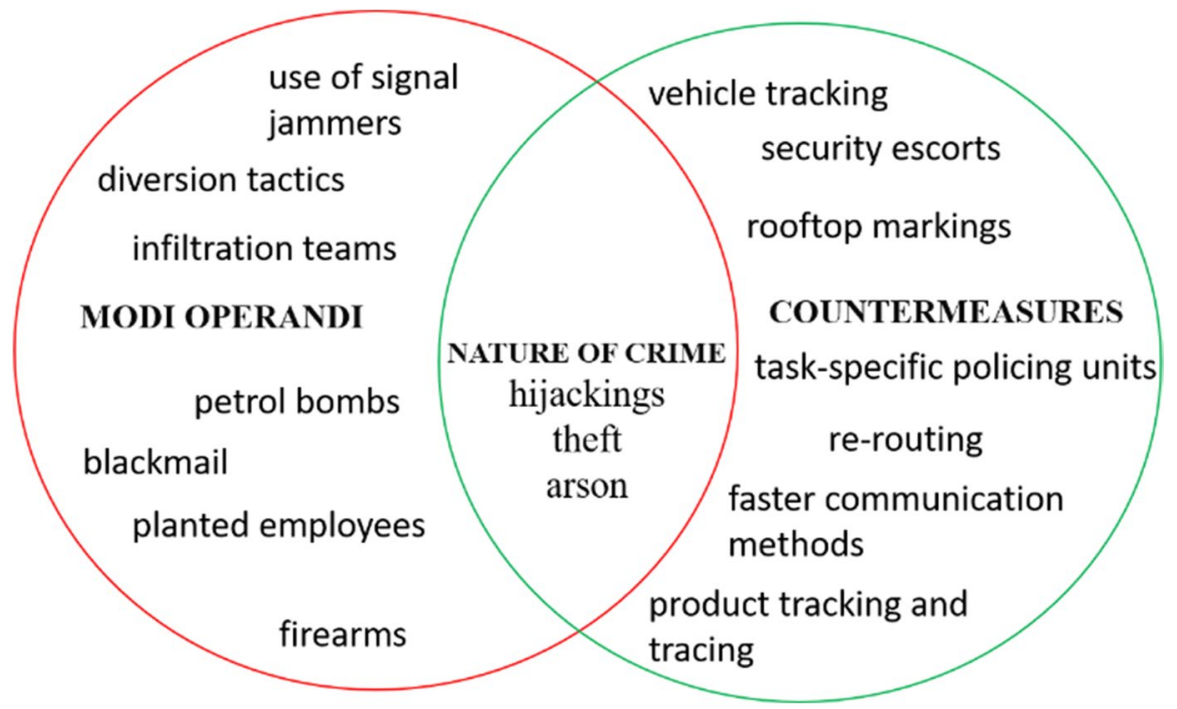

Fig. 3 Summary of M.O of Attacks and Countermeasures. Source: Author's presentation based on a 2016 interview with security expert (https://www.arrivealive.co.za/Truck-Hijackings-Crime-and-RoadSafety)

targeted pre-selected freighters. In random attacks, the attackers act without prior knowledge of the nature of goods in transit, while in the more sophisticated targeted attacks, trucks carrying specific often high-value goods are the primary target. Product-specific criminal syndicates have been known to coerce or somehow gain access to internal company communications to aid their operation and targeting. Preselection of target is not only limited to the merchandise being transported, as authorities have also reported that specific trucks have previously been specifically targeted, for example, trucks with tri-axle trailers. The criminal gangs make money either by selling the merchandise in the stolen trucks or by selling the trucks, as a scrap of in whole and there have been reports of trucks stolen in South Africa being sold in neighboring countries.

The increasingly organized nature of theft and hijackings has enabled criminal gangs to develop better techniques for carrying out their operations and evading authorities. The pirate gangs of Somalia included in their gangs, among others, highly experienced ex-militiamen who had previously participated in the civil war and technical experts who operated hi-tech equipment such as satellite phones, GPS, and military equipment to facilitate hijackings, according to some authors and military intelligence reports. Although not much is known about the structure and composition of hijackers of road freight carriers in South Africa, some of the methods such as signal jammers used in attacks indicate, to an extent, the presence of technical expertise within the gangs. Looking at reports of previous attacks on trucks, firearms are easily identified as the primary weapon used by criminal gangs, while petrol bombs are present nearly in other gang attacks and nearly in every report of an anti-immigrant-motivated attack on foreign drivers and trucks. Figure 3 is a brief 
illustration of methods, tools, and tactics used by criminals shown side-by-side with the countermeasures used by authorities and freight companies to fight theft and hijackings.

\section{Foreign freight drivers and trucks as a new target}

For many years, the waves of attacks on foreigners in South Africa mostly targeted small to medium business facilities owned by migrants in various parts of the country. However, recent waves of attacks have seen a new distinct target that is, foreign freight trucks or foreign drivers driving freight trucks on South African roads. As discussed in Section 2.2, there is a general belief in South Africa that, just like in other sectors, foreign drivers are stealing jobs from South Africans. The nature and level of violence used in attacks on trucks between 2018 and 2020 indicate that the motive was not to steal the trucks or their contents, but instead to cause damage, which was accompanied by serious threats to life and on occasion, the loss of it. Using tactics some of which were identical to those used by gangs in hijackings freight trucks are reported to have been slowed down before subsequently being shot at or set alight. On November 19 and 20, 2020, coordinated attacks on different South African highways were carried out resulting in the damage of at least 30 freight trucks in less than a week.

\section{Implications for South Africa and the SADC region}

The recent waves of attacks that saw foreign drivers and trucks specifically targeted could be seen as isolated incidents with a twist, and that they could be resolved and forgotten. On the other hand, however, it could spell the beginning of a wider problem for countries and supply chains that depend on South Africa to source and export their products. Not only that, regional efforts toward free trade and economic integration could potentially be undermined. Generally, South Africa has been slow to respond or present lasting solutions to the situation resulting in a backlash from its regional neighbors and the international community.

\section{Economic isolation and loss of business}

South Africa is an important member of the regional bloc SADC ${ }^{3}$ and its progressive road networks and highly developed port facilities attract business from companies based in the Southern African region. The state of infrastructure has been one of the key reasons that neighboring countries and enterprises based there have chosen South African ports over their competition despite the longer transit times and greater distance from ports of discharge to hinterland destination. However, should the threats on foreign personnel and trucks continue, countries may opt for

\footnotetext{
3 Southern African Development Community (SADC) is a 16-country intergovernmental organization established to further regional socio-economic, political and security cooperation.
} 
alternative ports available in the region and completely stop using South African ports for imports and exports. In theory, all, but one country in the region can conduct their imports and exports trade with overseas partners without using any ports in South Africa. Other major ports in the region include Dare salaam, Mtwara in Tanzania; Pemba, Nacala, Quelimane, Beira, and Maputo in Mozambique; Walvis Bay in Namibia, and; Lobito and Namibe in Angola. Additionally, major infrastructure works such as the dry port constructed by Zimbabwe at Walvis Bay in Namibia expand capacity and improve connectivity outside South Africa. The dry port commissioned in 2019 is strategically positioned and is set to increase container handling capacity from the current 350,000 to 750,000 TEUs, further reducing the neighboring countries' dependence on South African port facilities. In addition to the new terminal facilities, Namibia's road quality is superior to that of South Africa ${ }^{4}$. Another notable infrastructure facilitating freight transport in the region outside South Africa is the Kazungula bridge linking Botswana and Zimbabwe which, in addition to motor vehicle and pedestrian traffic, features a single railway track and was opened in 2021. With more trade facilitating infrastructure developments like these, countries around South Africa are gradually ridding themselves of their dependence on South Africa's infrastructure and increasing the practicality of alternatives in the region concerning connection to international markets. Additionally, in stark contrast to South Africa, other transit countries in the region namely Mozambique, Tanzania, and Namibia, do not have records of significant targeted attacks on the transport sector. There was an armed ambush on a truck in June 2013 in Mozambique which was linked to the rebel movement, Renamo ${ }^{5}$. No one was killed and there was no further escalation (Fig. 4).

Although it is highly unlikely, a regional boycott of South African ports and transit routes could have serious economic implications on South Africa. Immediately following attacks in 2015, the ministry of trade and industry was quoted as saying South Africa had lost "billions of Rands in export revenue" meaning that a wider and more coordinated boycott would have a grave impact on the economy. The attacks not only cost South Africa, but also the businesses and LLCs transiting through the country's road networks. The costs can come in form of extra expenses for security, extra fuel costs associated with diversions to avoid high-risk areas, delays in the delivery of goods, and loss of cargo and transport vehicles.

\section{International relations}

Africa has been working towards closer economic integration to ease the trade barriers among states. One of the most recent instruments for promoting trade is the African Continental Free Trade Area agreement whose main objectives include: promotion of trade, facilitation of industrialization, competitiveness, innovation, and value chain promotion. The agreement primarily focuses on eliminating non-tariff barriers

\footnotetext{
4 See Table 1.

5 Renamo, byname of Mozambican National Resistance, Portuguese Resistência Nacional Moçambicana, a militant organization and political movement.
} 


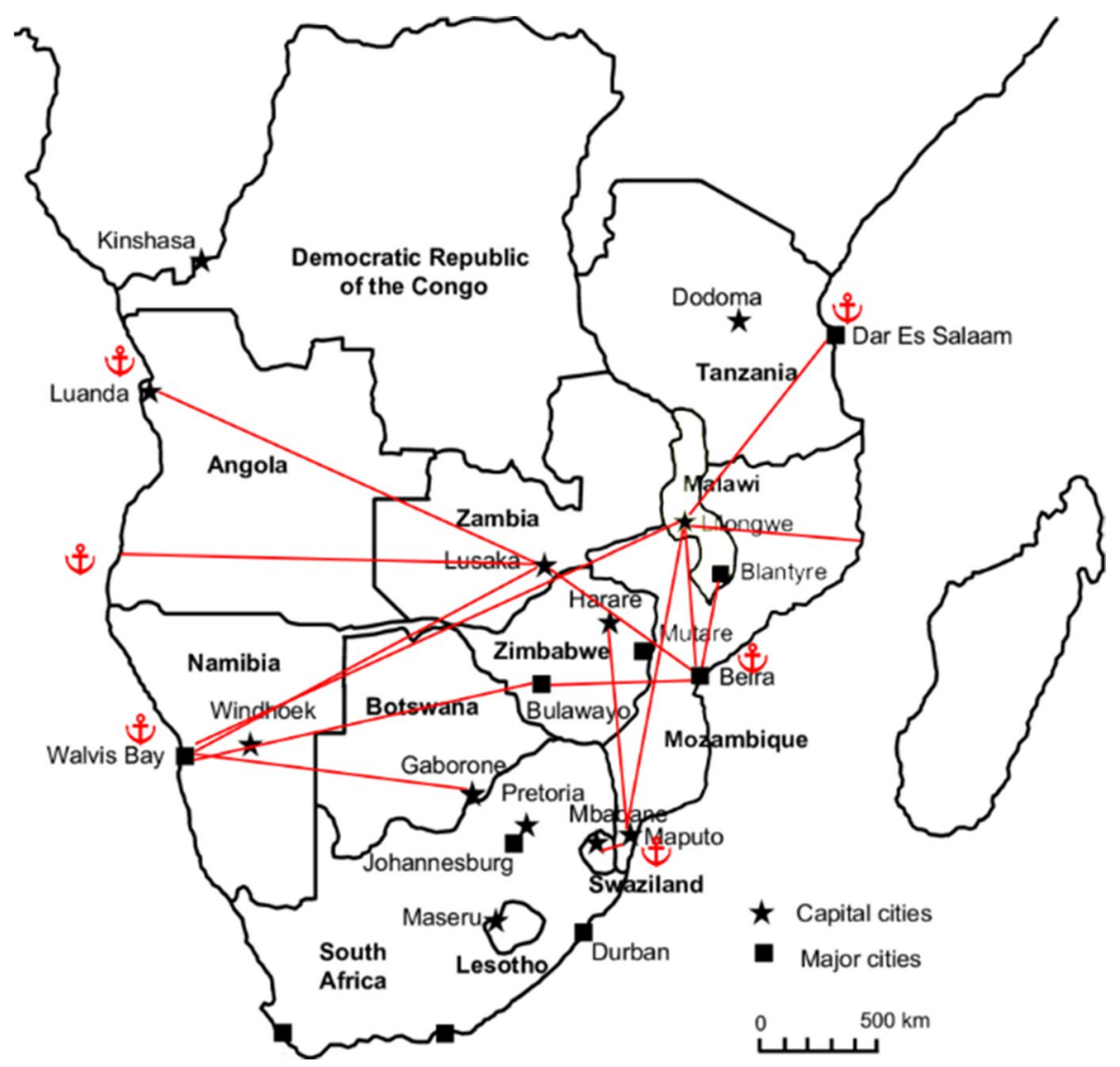

Fig. 4 A map depicting regional maritime port connections without South Africa. Source: Author's route depiction based on a map in Arntzen, Muchero, and Dube (Arntzen et al. 2004)

to trade and the movement of goods. However, the impeded movement of goods between countries due to threats such as truck hijackings and xenophobic violence, if not contained, would directly undermine the efforts of integration.

Following attacks on foreigners in South Africa in 2019, there were rising fears of reprisal attacks targeting South African citizens in other African countries. Many Nigerian businesses were targeted during that wave of attacks, along with others owned by Somalian, Kenyan, and Zambian nationals among others. It was following the attacks that South African-owned brands became targets of retaliatory looting in Nigeria. Along with Malawi, Rwanda, and the Democratic Republic of Congo, Nigeria boycotted the Economic Forum which South Africa was hosting. Following attacks on foreigners in South Africa in 2019, there were rising fears of reprisal attacks on South African citizens in other African countries. Many Nigerian businesses were targeted during that wave of attacks, along with others owned by Somalian, Kenyan, and Zambian nationals among others. It was following the attacks that South African-owned brands became targets of retaliatory looting in Nigeria. Along 
with Malawi, Rwanda, and the Democratic Republic of Congo, Nigeria boycotted the Economic Forum which South Africa was hosting. Although some countries' dependence is to a greater extent than others, a coordinated political protest and seclusion can have far-reaching implications. Perhaps an important illustration of the crippling effects of sour relations with regional neighbors is the three-and-a-halfyear blockade imposed on Qatar by its Gulf neighbors which took a toll on supply chains, private enterprises, and the Qatari economy in general. The blockade, which was in effect from July 2017 to January 2021 cost the gulf state an estimated 5 billion US dollars, with the national flag carrier Qatar Airways being one of the worsthit entities. Although the grounds for the blockade on Qatar were entirely different, it highlights the significance of sound international relations, especially with neighboring countries that are often significant economic partners, regardless of the size of their economies.

\section{Conclusions}

South Africa is key to the region's LLCs and will remain as such for the foreseeable future. For the undisrupted flow of trade between LLCs and or through South Africa, the significance of security, peace, and stability cannot be overstated. With regards to crime at the national level, there are signs of progress especially in rapid response to ongoing hijackings, thanks to improved collaboration and exchange of information between security organs and transporters. The efforts, however, are yet to reflect in the hijacking statistics- there hasn't been a significant reduction in the cases since $2014 / 2015$ as the figures remain relatively high compared to the years before. This could be attributed to the dynamic and unpredictable nature of the attacks that could make deterrent measures relatively difficult to enforce.

While solutions such as improved security, sharing of information, and the use of technology could address the common cargo security problem for road freight carriers, the underlying domestic social-economic challenges such as high unemployment, poverty, and inequality which are known to contribute to crime and often a source of violent protests remain unsolved. The complex nature of these challenges requires strong political interventions in form of policy reforms to facilitate the improvement of the welfare of the people. With the economic impact of COVID-19 on South Africa however, the social-economic challenges are most likely to worsen. The grievances about the social-economic challenges have been established as an aggravating element of xenophobic attacks against, especially black African immigrants. Contrary to popular belief, even if all the foreign workers were to be driven out of South Africa, it would still not have any impact on the current state of affairs with regards to domestic issues such as high unemployment. This is because such issues are attached to other more complex challenges such as national administrative policies in public institutions, and rampant corruption that compromises governance and service delivery in the country. Claims such as that foreigners are taking jobs away from South Africans have been dispelled, it is unlikely however that perception will change, especially since the influx of unskilled immigrants into the country continues. As much as free movement of people is key to free trade and integration, 
deliberate policy interventions regulating regional migration flows are necessary to minimize overwhelming other countries or appearing to do so, which has proven to be a key factor in the anti-immigrant rhetoric in South Africa.

Criminal attacks on freight trucks, in general, are not a new problem in South Africa, but the premeditated targeting of foreign drivers presents a new challenge at the regional level. Although the attacks against foreign freight trucks and drivers are born primarily out of violent anti-immigrant protests, the concentration of such attacks in criminal hotspots and similarity in the methods used could indicate influence or direct involvement of criminal gangs who take advantage of the chaos. Unlike the traditional attacks on freight trucks which center around monetary benefits, the attacks on foreign trucks and drivers have been to inflict damage as the majority were arson attacks- something that led to claims of deliberate economic sabotage and economic terrorism, by some observers.

While South Africa's transport infrastructure makes South Africa a reliable transit country for many LLCs, the recurring incidents of anti-immigrant protests and violent attacks continue to cause tension with its neighbors and effectively, make the country less preferred among the alternatives in the region. The underlying causes of violence and crime might be an internal matter for South Africa, but decisive concerted solutions are required at the regional level to ensure that all transnational truck drivers are protected regardless of which country they are in, along with the cargo they transport. Maritime transportation is the backbone of international trade even for LLCs, and on their part, transit countries such as South Africa have a responsibility of safeguarding the economic interests of LLCs through facilitating their access to maritime ports without obstacles- something also emphasized upon under priority number, the fundamental transit policy issues of the Vienna Program of Action for LLDCs. While strides are being made in other key areas of trade facilitation for facilitating trade for LLCs, security of transport does not appear to be receiving the attention it deserves although it has been mentioned in both the Almaty Program of Action and the Vienna Program of Action. In the former, key objectives included reducing loss, damage, and deterioration en route; and improving the safety of road transport and security of people of transport chains (UN-OHRLLS 2014, 2003). To the effect of security, the transport corridors that facilitate the movement of goods between countries should be given special designation with added layers of security and an oversight setup from representations of all countries that use the corridors, including the transit country. Other than treating them as isolated violent criminal acts in an individual country, attacks on freight carriers of other countries should be brought before the highest regional institutions and be dealt with as urgent international threats to regional and trade and economic integration and political cooperation. Despite close collaboration among regional security forces, there still exists no unified regional security apparatus to oversee security issue in the region. A great lesson can be learned from the effectiveness of Europol and the American Transportation Safety Administration (TSA) with regards to ensuring safety in the transport industry. The TSA, although set up initially to enhance aviation security, has seen its role expand to rail, urban transit, and port and maritime security alongside other security agencies in the USA (Oster and Strong 2008). Other than wait for a major disruptive criminal incident to necessitate the establishment of a regional 
law enforcement institution, now is the time that the southern African region considers a multinational law enforcement agency similar in structure to Europol in terms of jurisdiction to deal with organized crime, terrorism, and similar threats to the region's transportation industry in a similar fashion the TSA does in America. This however is heavily dependent on the political will of governments in the region which is the major impediment to policy implementation in the region.

\section{Limitations of this study}

The lack of centralized data on the cases of foreign freight truck attacks and casualties makes it difficult to track the figures and report with the detail required for the study-media sources offer limited and often conflicting information.

\section{References}

Arntzen J, Muchero M, Dube OP (2004) Global environmental change and food provision in Southern Africa. Explorations for a possible Gecafs Research Project in Southern Africa

Arrive Alive (2016) Truck Hijackings, Crime, and road safety. https://www.arrivealive.co.za/TruckHijackings-Crime-and-Road-Safety. Accessed 30 Jan 2021

Asoba SN, Mefi NP, Sibanda L (2020) African immigrant-owned businesses: A SWOT analysis perspective. Academy of Entrepreneurship Journal

BSI (2020) BSI \& TT club cargo theft report 2020: 2019 data. BSI

Burges D (2013) Cargo theft, loss prevention, and supply chain security. Elsevier, Amsterdam

Busari S, Swails B, Adebayo B (2019) South Africa closes embassies in Nigeria, fearing reprisal attacks. https://edition.cnn.com/2019/09/05/africa/south-africa-xenophobia-attacks-intl/index.html. Accessed 2 Feb 2021

Calder S (2021) End of Qatar air blockade opens up flying in the Gulf. January 8. https://www.indep endent.co.uk/travel/news-and-advice/qatar-airways-flight-detour-saudi-egypt-b1782668.html. Accessed 2 Feb 2021

Cofelice A (2018) African continental free trade area: opportunities and challenges. The Federalist Debate De Gruyter, November 32-35. https://doi.org/10.2478/tfd-2018-0032

Collier P (2007) Bottom billion. In: Ritzer G (ed.) The Blackwell Encyclopedia of Sociology. https:// doi.org/10.1002/9781405165518.wbeos1025

Crush J, Williams V, Peberdy S (2005) Migration in southern Africa. Policy analysis and research programme of the Global Commission on International Migration

Crush J, Chikanda A, Caroline, Skinner (2015) Mean streets: Migration, xenophobia and informality in South Africa. Southern African Migration Programme, Ontario

Cujan Z, Fedorko G (2016) Supplying of assembly lines using train of trucks. Open Eng 6:426-431. https://doi.org/10.1515/eng-2016-0057

Department of Statistics South Africa (2020) Quarterly Labour Force Survey Q3: 2020. Department of Statistics South Africa, Pretoria

Dube G (2018) Afrophobia in Mzansi? Evidence from the 2013 South African Social Attitudes Survey. J South Afr Stud 44(6):1005-1021

Ekwall D, Lantz B (2015) Modi operandi for cargo theft in EMEA-A seasonality analysis. J Transp Secur 8:99-113

Fajnzylber P, Lederman D, Loayza N (2002) What causes violent crime? Eur Econ Rev 46:1323-1357

Faye ML, McArthur JW, Sachs JD, Snow T (2004) The challenges facing landlocked developing countries. J Hum Dev 5(1):31-68

Focus on Transport and Logistics (2019) Truckers' road to hell. Focus on Transport, July 2. https:// focusontransport.co.za/truckers-road-to-hell/. Accessed 19 Jan 2021 
Freewest media (2020) 'Economic terrorism': Attacks on foreign truck drivers intensify in South Africa. Pretoria, December 12. https://freewestmedia.com/2020/12/12/economic-terrorism-attac ks-on-foreign-truck-drivers-intensify-in-south-africa/. Accessed 16 Jan 2021

HRW (2019) South Africa Events of 2019. https://www.hrw.org/world-report/2020/country-chapters/ south-africa\#28ab32. Accessed 16 Jan 2021

Justus M, Ceccato V, Moreira GC, Kahn T (2018) Crime against trading: the case of cargo theft in São Paulo. In: Retail Crime. Crime Prevention and Security Management, by V Ceccato and R Armitage, 297-323. Palgrave Macmillan. https://doi.org/10.1007/978-3-319-73065-3_12. Accessed 21 Jan 2021

Kaluba M (2020) Zambian trucks burnt in South Africa xenophobia. November 26. https://www. zambiawatchdog.com/zambian-trucks-burnt-in-south-africa-xenophobia/. Accessed 28 Dec 2020

Mamabolo, Malemela A (2015) Drivers of community xenophobic attacks in South Africa: poverty and unemployment. J Transdiscipl Res South Afr 11(4):143-150

Masenya MJ (2017) Afrophobia in South Africa: a general perspective of xenophobia. Bangladesh e-J Sociol 41(1):81-88

Mlilo S (2019) Xenowatch Factsheet: 1 Incidents of Xenophobic Violence in South Africa: January - September 2019. The African Centre for Migration \& Society (ACMS), University of Witwatersrand, Braamfontein

Nkomo J (2018) 3 Zambian Truck Drivers Petrol bombed and trucks burnt in South Africa. May 10. https://zambianews365.com/3-zambian-truc/. Accessed 12 Jan 2021

Numbeo (2021) Crime Index by Country. https://www.numbeo.com/crime/rankings_by_country.jsp. Accessed 12 Feb 2021

OEC (2018) The observatory of economic complexity. https://oec.world/en. Accessed 6 Feb 2021

Okpareke P (2018) Racism and Xenophobic Attacks in South Africa

Onuoha FC (2010) Piracy and maritime security off the horn of Africa: connections, causes, and concerns. Afr Secur 3(4):191-215

Onuoha F (2009) Sea piracy and maritime security in the Horn of Africa: The Somali coast and Gulf of Aden in perspective. Afr Secur Rev 18(3):31-44

Oster CV, Strong JS (2008) A review of Transportation Security Administration funding 2001-2007. J Transp Secur 1(1):37-43

Pristrom S, Li KX, Yang Z, Wang J (2013) A study of maritime security and piracy. Marit Policy Manag 40(7):675-693

Road Safety Administration (2019) Guidelines on maximum weights and dimensions of mechanically propelled vehicles and trailers. Including Manoeuvrability Criteria.

SAPS (2020) Crime statistics: Crime situation in republic of South Africa- Twelve (12) months (April 2019-March 2020). South African Police Service

Singh K (2020) IOL. November 27. https://www.iol.co.za/mercury/news/80-of-truck-drivers-aresouth-african-028c074b-b6ed-4a08-a484-890113ddc373. Accessed 16 Jan 2021

Solomon H, Kosaka H (2014) Xenophobia in South Africa: Reflections, narratives and recommendations. South Afr Peace Secur Stud 2(2):2-29

Tengeh RK (2011) A business framework for the effective start-up and operation of African immigrant-owned businesses in the Cape Town Metropolitan area. South Africa. Cape Town

Thela L, Tomita A, Maharaj V, Mhlongo M, Burns JK (2017) Counting the cost of Afrophobia: Postmigration adaptation and mental health challenges of African refugees in South Africa. Transcult Psychiatry 54(5-6):715-732

Tshishonga N (2015) The impact of xenophobia-Afrophobia on the informal economy in Durban CBD, South Africa. The Journal for Transdisciplinary Research in Southern Africa 11(4):163-179

TT Club \& BSI Screen Intelligence (2020) Freight crime in South African supply chains. BSI

TT CLUB \& BSI SCREEN Intelligence (2020) Freight Crime in South African Supply Chains

UNDP (2020) Human Development Report 2020: The next frontier. Human development and the Anthropocene. United Nations Development Programme, New York

UN-OHRLLS (2003) Almaty programme of action: Addressing the special needs of landlocked developing countries within a new global framework for transit transport cooperation for landlocked and transit developing countries. United Nations

UN-OHRLLS (2014) Vienna programme of action for landlocked developing countries for the decade 2014-2024. United Nations 
Waiganjo AG (2018) Coping mechanisms in navigating Xenophobia-Afrophobia-related challenges within the transnational space: case of Somali refugee women in Gauteng, South Africa. J Int Migr Integr 19(3):649-666

WEF (2017) World Economic Forum competitiveness report: Road quality index 2016 - 2017

WEF (2018) World Economic Forum Competitiveness Report: Road quality index 2017 - 2018

World Bank (2019) The World Bank. https://data.worldbank.org/indicator/NY.GDP.MKTP.CD?locat ions=ZA. Accessed 23 Dec 2020

Publisher's Note Springer Nature remains neutral with regard to jurisdictional claims in published maps and institutional affiliations. 